\title{
The Gendered Impacts of Drug Policy on Women: Case Studies from Mexico
}

\author{
Corina Giacomello
}

\begin{abstract}
This chapter looks at women involved in drug offences and women who use drugs, from the perspective of the intersection of three axes: i) gender relationships and gender systems, ii) development, and iii) drug policy. Its purpose is to analyse the impacts of drug policy on women from a gender perspective, with a focus on two groups of 'women in detention': incarcerated women and women in residential treatment centres. The paper argues that current drug policies are part and parcel of patriarchal structures that underlie violence against women and children and undermine gender equality and development.

The international framework of drug control generates, via prohibition, illicit drug markets and drug trafficking organisations, which mirror hegemonic gender systems and treat women and children as disposable objects, maintaining sexist structures that lead to the exploitation of women's labour by their male partners, patriarchal relations with regard to illicit waged labour, and patriarchal violence and culture. The other direct results of the implementation of international drug policy are the use of incarceration as a means of deterrence and the growing number of women in prison for drug offences.

Also in the case of women who use drugs, current drug policies contribute, with practical and discursive elements, to the reproduction and justification of violence against women and girls. The two groups of women in detention analysed in this chapter, instead of being accompanied by communities, families and state institutions that address and attempt to repair the suffering and the crimes committed against them, are further isolated through institutionalisation in legal or illegal sites, in which violence against women is further reproduced and development is hindered.
\end{abstract}

\section{Introduction}

We cleaned it [marijuana], we packaged it, we bundled it up and it was like a process. In the town, people were happy when that kind 
of work began, because even children, and old people, people of all ages were involved.

GABY, Female Prison Centre Tanivet, Oaxaca, Mexico

Gabriela Cruz ('Gaby') grew up in a rural area in one of the most stunning states of Mexico: Oaxaca. Situated in the south-east, Oaxaca is a place of many beauties and treasures: a varied gastronomy, lush jungles, amazingly preserved pyramids, virgin white-sanded beaches, a multitude of indigenous languages, and mind-enhancing plants-Maria Sabina's 'little children' full of psilocybin, salvia divinorum, and Gaby's village's main source of employment, marijuana. Nonetheless, Oaxaca's abundant contributions to the world's cultural and spiritual growth contrast with the national and local development context.

Half of the Mexican population lives in poverty, and access to education, health, social security, housing and basic services has decreased since 2008. In this scenario, women are further discriminated against in several areas. The Human Development Index (HDI) for men is 0.789 whereas women's is $0.75^{2}$, and men's 'estimated gross national income per capita' is twice that of women's (UNDP, 2018, 35).

In the Gender Inequality Index, Mexico ranks seventy-sixth. Another striking number is the adolescent birth rate: 60.3 births per 1,000 women aged 15-19 (UNDP, 2018, 39), compared to a global average of 44. Teenage pregnancies are a regional problem: according to the Pan American Health Organization (PAHO), 'although total fertility (number of children per woman) in Latin America and the Caribbean (LAC) has declined over the past 30 years, adolescent fertility rates have only dropped slightly during that period and continue to be the second highest in the world, surpassed only by those in sub-Saharan Africa' (PAHO, 2017, 13).

Gaby fits into these statistics. She had her first daughter when she was 15 years old. Her pregnancy was the product of rape by a man from her village. Gaby, a victim of violence against children (Lenzer, 2015) and of gender-based violence against women and girls (Council of Europe, 2011), was also, by then, a victim of one of the worst forms of child labour (ILO, 1999). Since the age of twelve, she had been carrying small packages of marijuana to Mexico City. Her recruiter was also a man from her village.

When she grew up, she fell in love with a drug trafficker and became pregnant again. The trafficker abandoned her. She had no money to pay for private healthcare, and public healthcare in Mexico is insufficient, especially in rural

1 See the figures in 'Medicion de pobreza 2008-2018, Estados Unidos Mexicanos', Coneval, https://www.coneval.org.mx/Medicion/PublishingImages/Pobreza_2018/Serie_2008-2018. jpg (accessed on 5 May 2020). 
areas. Gaby's child was born with physical and brain paralysis, and Gaby continued to carry marijuana in order to pay for medical examinations.

So far, the state had been almost absent from Gaby's life. Neither the sexual violence nor the child-labour exploitation merited its attention or intervention. Poverty and underdevelopment were balanced by the employment provided by illicit crop cultivation, and lack of healthcare was 'compensated' with local knowledge of herbs and infusions.

One day, the state became interested in Gaby. She was arrested when transporting marijuana and given a ten-year prison sentence. She was locked away together with her child and finally became a number. The only official trace of Gaby lies in the registers of another global phenomenon with specific impacts in Mexico and Latin America: international drug policy. Mexico is not only host to opium and marijuana cultivation, cocaine and heroin flows, and other facets of international drug trafficking (UNODC, 2019). It is also home to some of what the United Nations Office on Drugs and Crime (UNODC) has labelled 'collateral consequences' (UNODC, 2008)—namely, the increasing incarceration of low-level offenders and drug users as well as lack of treatment for dependent drug users.

In light of the drug policy paradigm, where rates of incarceration are an indicator of success (Bewley-Taylor, 2016), Gaby's prison sentence represents a step forwards, towards a 'drug free world'. But as we dissect Gaby's story and peel back the layers of gender-based violence, social exclusion and racial discrimination, as well as the impacts of imprisonment on her child, the balance shifts towards other possible interpretations. Gaby's story becomes part of a global trend: the gendered impacts of drug policy on women and development.

\section{1}

Main Arguments, Methodology, and Contents

The impacts of drug policy on women can be analysed from the particular situation of, at least, four groups: i) incarcerated and formerly incarcerated women and girls, ii) women who use drugs, iii) female children and adolescents with an incarcerated 'appropriate adult' (an approximate form of legal guardianship) or with an appropriate adult in residential drug treatment, and iv) women carers of people in prisons or of drug users.

This chapter focuses on the first two groups, specifically on women detained in prisons and in drug treatment centres. This choice of focus is informed by the author's expertise, but also by the intersection of gender beliefs with detention, ${ }^{2}$

2 Detention is understood in terms of the General Provision of the Principles and Best Practices on the Protection of Persons Deprived of their Liberty in the Americas (IACHR, 2008), 
which constitutes a symbolic and material space for the reproduction of multiple forms of gender-based violence against women and girls.

Drug policy is understood according to the definition provided by the World Health Organization (wHO):

In the context of psychoactive drugs, the aggregate of polices designed to affect the supply and/or the demand for illicit drugs, locally or nationally, including education, treatment, control, and other programmes and policies. In this context, "drug policy" often does not include pharmaceutical policy (except with regard to diversion to non-medical use), or tobacco or alcohol policy. ${ }^{3}$

National drug policy is framed by the United Nations' (UN) three conventions on drugs ${ }^{4}$ as well as other relevant documents developed at the international level. ${ }^{5}$ In the case of women, three documents highlight women's

which states: 'For the purposes of the present document, "deprivation of liberty" means: Any form of detention, imprisonment, institutionalisation, or custody of a person in a public or private institution which that person is not permitted to leave at will, by order of or under de facto control of a judicial, administrative or any other authority, for reasons of humanitarian assistance, treatment, guardianship, protection, or because of crimes or legal offences. This category of persons includes not only those deprived of their liberty because of crimes or infringements or non-compliance with the law, whether they are accused or convicted, but also those persons who are under the custody and supervision of certain institutions, such as: psychiatric hospitals and other establishments for persons with physical, mental, or sensory disabilities; institutions for children and the elderly; centres for migrants, refugees, asylum or refugee status seekers, stateless and undocumented persons; and any other similar institution the purpose of which is to deprive persons of their liberty'.

3 In its Lexicon of alcohol and drug terms, available on https://www.who.int/substance_abuse/ terminology/who_lexicon/en/ (accessed on 5 May 202O), the wHO provides two definitions of drug policy. The second is: 'In the context of WHO's Action Programme on Essential Drugs, 'national drug policy' refers to a national pharmaceutical policy concerning the marketing, availability, and therapeutic use of medicines. wHO recommends that every country should have such a policy, formulated in the context of a national health policy. The wHO List of Essential Drugs is an effort to assist developing countries to develop a pharmaceutical policy attuned to allocating scarce funds for pharmaceuticals on the basis of health needs rather than market considerations'. This chapter uses only the first definition, which is reproduced in the chapter's main text.

4 The Single Convention on Narcotic Drugs (1961) as amended by the 1972 Protocol; the Convention of Psychotropic Substances (1971); and the United Nations Convention against Illicit Traffic in Narcotic Drugs and Psychotropic Substances, of 1988.

5 These include - to name only some of the more relevant documents from recent years - the Outcome Document of the United Nations General Assembly Special Session (UN General Assembly, 2016), adopted in April 2016; the United Nations system common position supporting the implementation of the international drug control policy through effective inter-agency 
gender-specific exposure to discrimination and violence within the context of drug trafficking and drug use and call on international agencies and member states to mainstream gender in drug policy, take into account women's specific needs and realities, and adopt gender-centred actions in drug policy design and implementations. These documents are the UN Women (2014) policy brief A gender perspective on the impact of drug use, the drug trade, and drug control regimes, the Commission on Narcotic Drugs' resolution Mainstreaming a gender perspective in drug-related policies and programmes (UN CND, 2016) and the Outcome Document of the United Nations General Assembly Special Session on Drugs (UN General Assembly, 2016). All of these documents provide public policy proposals, which aim to take into account the gender dimension of drug use and drug trafficking and implementing women-centred drug policies, among them:i) implement alternatives to the incarceration of women accused of non-violent, minor offences and who are pregnant or the primary or sole carers of small children; ii) gather and share sex-disaggregated data; iii) provide women who use drugs with access to treatment services tailored around their needs; iv) work towards the elimination of violence and discrimination against women; and v) guarantee women's inclusion in the design, implementation, evaluation and monitoring of drug policy.

This chapter acknowledges the relevance of the analysis included in the above-mentioned documents and agrees on the general tone and contents of their proposals. It also, however, stresses the importance of placing drug policy under scrutiny using the lens of gender and feminist critique. To such ends, women's narratives are the main methodological resource used to unpack some of the gendered impacts of drug policy on women in detention and their negative impact on the achievement of Sustainable Development Goal (SDG) number 5: 'Achieve gender equality and empower all women and girls' (UN General Assembly, 2015, 14). This chapter argues that current drug policies foster violence against women and children and further undermine gender equality and development.

The case studies of women in prison for drug offences presented in the second section of this chapter are part of an awareness-raising and lobbying effort developed with the civil society organisations EQUIS Justice for Women (Mexico) and the Washington Office on Latin America (woLA). The cases are

collaboration, adopted in November 2018 (UN Chief Executives Board for Coordination, 2019, 12-14); and the Commission on Narcotic Drugs Implementation of All International Drug Policy Commitments. Follow-up to the 2019 Ministerial Declaration Strengthening Our Actions at the National, Regional and International Levels to Accelerate the Implementation of Our Joint Commitments to Address and Counter the World Drug Problem (UN CND, 2019). 
discussed within the larger framework of women in prison for drug offences. They benefit from the author's over ten years of empirical research, mostly in Mexican female and mixed prisons, as well as comparative law and policy research on women in prison for drug offences with a focus on Latin America (Giacomello, 2013a, 2013b, 2017a, 2017b; Giacomello, Erreguerena and Blas, 2017).

The information presented here on women who use drugs and are deprived of their liberty in drug treatment centres or in prison is the result of one year of research, including nine months of field work in i) two prisons, ii) two public and one semi-private treatment centre, iii) a semi-private opioid-substitutiontreatment clinic, and iv) five private treatment centres (for people with low incomes) - three of these being for women and girls only and the others being for both men and women and adolescents of both sexes - in four states of Mexico.

Information on the women and girls who generously participated in semistructured interviews with the author is systematised in a figure in the corresponding section and the analysis is based on the entirety of the data collected, with two stories being narrated in more detail to give a deeper sense of the general findings. As can be seen from Figure 12.2, this information is not homogenous for all the informants as a result of the methodological choice of the author. Given the delicacy and intimacy of the topics under discussion and the life experiences women and girls shared in our fragile and time-bound space of trust, the interview was conducted as a conversation and not a closed-answer questionnaire with open questions. Therefore, if some information was not provided when asked for, if the context (time limits, a situation of danger, group interview, or the presence of authorities, among other factors) acted as an obstacle to the development of certain answers, or if the informant simply took control of the interview and 'used' it as a space for being listened to, the author did not stress particular missing elements, rather opting to preserve the continuity and confidence of the conversation.

Both the individual and the group interviews focused on three topics: i) the women's relationship with drugs; ii) the intersection of drug use with life experiences, which ended up being mostly a narrative of cyclical gender-based violence and different forms of institutionalisation (either in juvenile detention centres, drug treatment centres, prisons, or institutions for children who had been abandoned or ill-treated by their families); and iii) life conditions in treatment centres.

In the case of women in prison, we also talked about their crimes-mainly their circumstances rather than the legal process. Involvement in a criminal offence (robbery, homicide, kidnapping, drug dealing) was mostly related to relationships developed in parallel to drug use and/or linked to emotional relationships. 
Group interviews mainly took place in prisons due to two main factors: the author had the opportunity to interview between four and ten women during each prison visit in a constrained amount of time (usually around three hours). In order to listen to all of the women who attended the interviews without keeping them waiting or cancelling at the last minute, it was more convenient to develop the individual interview in a group context. Of course, participation in a group interview only occurred if and when women felt comfortable with it. The second factor, which reinforced the first, is that prison authorities brought the women to me in groups, although this did not happen in all prisons. In other cases, collective interviews happened because women and girls requested it. In one case, for example, two inmates wanted to be interviewed together but not with other inmates. In a public treatment centre, two adolescents asked to be interviewed together and the centre also recommended it, since one of them had experienced a crisis after sharing, during a collective therapeutic session, that she had been a victim of rape. She was eager to be interviewed and to talk about her experience, but only if accompanied by her friend.

At the beginning of each individual or group interview, the women and girls were informed of the structure and purpose of the encounter and were invited to leave whenever they needed or wanted to, and to disclose only the type and amount of information they felt comfortable sharing. They were also promised that if they decided to withdraw from the interview, there would be no repercussions.

Generally speaking, I made efforts to make them feel at ease, listened to, and free to leave at any time, and also to discuss topics they chose if it helped make them feel better. In general, the experience of being listened to seemed to prove successful and have a soothing effect. In one case in particular, in a drug treatment centre in which I myself felt in danger, the girls wanted to talk to me even if they knew they would probably be punished for it. Despite my intention to leave once I understood the gravity of the situation, two girls insisted on being interviewed, because they were completely isolated and had nobody to talk to. I underlined that talking to me could put them in danger and that I had no means of protecting them. I added, however, that if they felt the need to talk, I would stay there until the centre's owners (a protestant pastor and his wife) told me to leave, which occurred a couple of interviews later, in threatening tones.

Lastly, it must be pointed out that the author's access to these interviewees was mainly due to her personal and professional contacts rather than to institutional processes. The latter only played out in the case of semi-public treatment centres. In positive terms, this gave the author access to data that are often difficult to gather. Nevertheless, it also mirrors how institutional barriers 
or, in the case of some drug treatment centres, efforts to conceal illegal conduct often impede research that can benefit the development of public policies.

This chapter develops as follows. Section 2, 'Discrimination and Violence Against Women', outlines some theoretical concepts, as well as data that speak to the persistence of unequal gender relationships. Section 3 , 'Gender and Drug Policy' includes a core of case studies that are part of the author's fieldwork on women in prison for drug offences and women drug users in public and private treatment centres in Mexico. The chapter ends with some final reflections on the challenges to mainstreaming gender in drug policy.

\section{Discrimination and Violence against Women}

I was taught that women must obey their husbands.

SONIA, sentenced to 5 years for cocaine possession, Female Prison Centre Tanivet, Oaxaca, Mexico

\subsection{Gender, Gender Systems and Patriarchal Structures}

In this chapter, the concept of gender is understood i) as an identity organiser of binary, unequal social structures in which men have power over women; ii) as a relational notion; and iii) in terms of the gender system.

It is important to underline that the fictional binary division between men and women as the only possible sexual and gender identities, which is one of the pillars of gender systems, is preserved in this piece. This is not because the author believes that it accurately describes sexual and gender identities, but because it is part of the gender systems that underpin and build the interviewed women's narratives and experiences, as well as the way drug policy refers to gender. Other gender identities, and the transformative power of what we mean by gender and how it is enacted in individual and social contexts, are therefore not part of the theoretical framework of this chapter.

Gender as a 'background identity' (Ridgeway, 2009) and 'primary form of power relationship' (Wallach Scott, 2008) refers to how characteristics, roles, attributes and expectations are built on people's perceptions of themselves and others. This is valid in people's individual and social relationships, in their relationships with their own bodies and sexual identities, and in how they are perceived and expected to be by others. Gender identity interweaves with other social identity constructs, such as race, ethnicity and class, and forms part of multi-layered levels of social stratifications and stereotypes attached to people and social groups.

Differences between men and women, men and men, and women and women operate on a horizontal scale, but also on a vertical one (Ridgeway and 
Correll, 2004), with women being traditionally portrayed as inferior to men. Héritier (2007) defines women's lower social status with the concept 'differential valence of sexes', which is always present, although with differences between societies, social groups and historical times.

Gender, therefore, constitutes a changing set of cultural beliefs and symbols that underlie the ongoing construction and reinterpretation of what we mean by the binary and asymmetrical conceptions of 'men' and 'women' and how such conceptions are enacted by individuals, relationships and social contexts.

Gender roles and attributes are transmitted in the shape of a binary system of prohibitions and expectations. In other words, gender is both proscribed and prescribed. The combination of gender prescriptions and proscriptions constitutes what is here defined as 'gender axioms' - that is, particular sets of behaviours that both respond and correspond to the beliefs that lie beneath them. For instance, women are expected to love their babies and are proscribed from taking drugs during pregnancy. Such prescription and proscription are glued to each other by the traditional gender belief-rooted in the interpretation of women's bodies - that reproduction is not only biologically possible, but naturally desired. Women who do not want to become mothers have to explain their decision, whereas that does not happen to women who opt for motherhood. Furthermore, the 'natural role of women as life-givers' should find a cultural correspondence in the 'cultural role of women as carers', thus guaranteeing a continuum between sex and gender identity that can be presented as a coherent product of gender-based prescriptions and prohibitions. Not fulfilling the prescription or transgressing the proscription leads to a breach of the gender axiom, which in turn leads to stigma and punishment.

Gender axioms encompass both hegemonic gender beliefs and alternative gender beliefs (Ridgeway and Correll, 2004), with the former prevailing on the latter in terms of how people expect to be treated and conduct their behaviour. Hegemonic and alternative gender axioms are, however, not fixed, isolated structures, but exhibit interplay with each other and can be incorporated into an individual's life story simultaneously. This is the case with women involved in drug offences for example. Non-hegemonic agency (namely, transporting drugs) is framed in some of the narratives as an act of positive transgression (a choice to commit a crime), but also as the acting out of hegemonic gender beliefs and roles, such as being a poor, single mother who has to provide for her children, or being an obedient spouse. The combination of agency and genderbased victimisation, then, is not only an analytical approximation (Giacomello, 2017a) but also a narrative nurtured by a rich and plural array of gender beliefs that coexist despite binary representations of 'good' and 'bad', 'hegemonic' and 'alternative' gender-based behaviours. 
Gender, therefore, must be understood not only as an identity axis and a relationship's organiser, but also as a system that operates as a matrix of mandates and hierarchies that constrain and direct people's conduct. These are also inherently difficult to resist - in part because of the fear of stigma, and partly because of the rewards of attaining 'normality' (Goffman, 1961). But also because one is always situated within gender relationships-at the interpersonal or self-identity level, as well as in the normative and cultural arrangements that regulate societies as a whole, and in its practical effects on formal and informal institutions such as language, religion, family, education, state institutions, economic organisation and political structures.

Gender systems are in constant flux and changes are reflected in the advancement of women in all spheres. As it will be shown through data and women's narratives in the following sections, however, the 'inferiorisation' of women is a persistent element. The 'differential valence of sexes' is embodied in and reproduced through the six patriarchal structures described in Walby's Theorizing Patriarchy: i) a patriarchal mode of production in which women's labour is expropriated by their husbands; ii) patriarchal relations with regard to waged labour; iii) the patriarchal state; iv) male violence; v) patriarchal relations in sexuality; and vi) patriarchal culture. These six partially independent structures compose patriarchy 'as a system of social structures, and practices in which men dominate, oppress and exploit women' (Walby, 1989, 214). These structures also interweave and manifest themselves in the realm of drug trafficking, drug policy, and their effects on women.

\subsection{Data on Gender Inequality}

Despite the fact that the last century has witnessed enormous progress towards gender equality, women still lag behind men in all areas: education, health, economic independence and access to resources, economic competitiveness, and participation in political decision-making bodies.

The World Economic Forum's Global Gender Gap 2018 'benchmarks 149 countries on their progress towards gender parity on a scale from o (disparity) to 1 (parity) across four thematic dimensions - the sub-indexes Economic Participation and Opportunity, Educational Attainment, Health and Survival, and Political Empowerment' (WEF, 2018, vii). The main findings show that the gender gap lies at 32 per cent and that the overall global gender gap will close in 108 years. ${ }^{6}$

6 The methodology and quantitative analysis behind these figures are described in WEF $\left(2018,3^{-7}\right)$. 
Gender inequality not only constitutes a violation of human rights, it hinders the development of society as a whole. As outlined in the Human Development Indices and Indicators report:

The disadvantages facing women and girls are a major source of inequality and one of the greatest barriers to human development progress. [...]. Worldwide, the average HDI value for women (0.705) is 5.9 percent lower than that for men (o.749) [...]. Much of the gap is due to women's lower income and educational attainment in many countries. The gender gap is widest in low human development countries, where the average HDI value is 13.8 percent lower for women than for men.

UNDP, 2018, $5^{-6}$

The 2030 Agenda for Sustainable Development includes 17 interdependent and indivisible goals with 169 associated targets. As outlined in the introduction to this chapter, goal number 5 advocates for gender equality and the empowerment of women and girls. The goal breaks down into specific targets ${ }^{7}$ that reflect the main obstacles to reaching equality between men and women: violence against women, women's double or triple work burden especially in unpaid care-giving activities related to domestic tasks and child rearing (that is, caring for others at the expense of care for oneself), and women's greater exclusion from formal employment and therefore social protection, not to mention glass ceilings and pay gaps, which constitute

7 The targets are: '5.1 End all forms of discrimination against all women and girls everywhere; 5.2 Eliminate all forms of violence against all women and girls in the public and private spheres, including trafficking and sexual and other types of exploitation; 5.3 Eliminate all harmful practices, such as child, early and forced marriage and female genital mutilation; 5.4 Recognize and value unpaid care and domestic work through the provision of public services, infrastructure and social protection policies and the promotion of shared responsibility within the household and the family as nationally appropriate; 5.5 Ensure women's full and effective participation and equal opportunities for leadership at all levels of decision-making in political, economic and public life; 5.6 Ensure universal access to sexual and reproductive health and reproductive rights as agreed in accordance with the Programme of Action of the International Conference on Population and Development and the Beijing Platform for Action and the outcome documents of their review conferences; 5.a Undertake reforms to give women equal rights to economic resources, as well as access to ownership and control over land and other forms of property, financial services, inheritance and natural resources, in accordance with national laws; 5.b Enhance the use of enabling technology, in particular information and communications technology, to promote the empowerment of women; 5.c Adopt and strengthen sound policies and enforceable legislation for the promotion of gender equality and the empowerment of all women and girls at all levels' (UN General Assembly, 2015, 18). 
some of the most powerful tools in the ongoing oppression of women and girls.

The UN Economic Commission for Latin America and the Caribbean (ECLAC) Quadrennial report on regional progress and challenges in relation to the 2030 Agenda for Sustainable Development in Latin America and the Caribbean (ECLAC, 2019) shows that Latin America is the most unequal region in the world. Income distribution can be illustrated by examining households' share of total income. The highest income quintile (quintile v) accounts for about 45 per cent of total household income, while the lowest-income quintile (quintile I) receives, on average, just 6 per cent (ECLAC, 2019, 114). Also, after more than a decade of falls in poverty and extreme poverty, both have increased since 2015 . Poverty does not affect all people equally: the report shows that 'women make up a higher proportion of those living in poor households. In Latin America, the femininity index of poverty remained stable and high between 2012 and 2017, at around 113' (ECLAC, 2019, 116), which means that for 100 men from the age of 20 to 59 living in poverty there are 113 women in a similar situation.

\subsection{Violence against Women}

Gender-based violence is crucial to understanding women's participation in drug offences as well as the development of dependent drug use.

The Council of Europe's Convention on preventing and combating violence against women and domestic violence, also known as The Istanbul Convention, defines gender-based violence against women as 'violence that is directed against a woman because she is a woman or that affects women disproportionately' (Council of Europe, 2011, 8). The UN High Commissioner for Human Rights defines gender-based violence and its intersections as follows:

Gender-based violence is considered to be any harmful act directed against individuals or groups of individuals on the basis of their gender. It may include sexual violence, domestic violence, trafficking, forced/early marriage and harmful traditional practices. An understanding of how gender intersects, for instance, with race, religion, economic situation, political affiliation and geography is also critical to addressing patterns and forms of gender-based violence.

OHCHR, 2014

The intersectional approach - that is, the recognition of the intersection of multiple inequalities (Walby, Amstrong and Strid, 2012) and how this affects different people and groups in different ways-is key to understanding the gendered impact of drug policies. For example, the oppression experienced 
by white middle-class women is not the same as that experienced by women of colour or indigenous women. Furthermore, women in detention, either accused of a drug offence or in treatment centres, simultaneously experience gender-based violence. This includes sexual violence, intersectional forms of violence and discrimination (for being poor, for not fulfilling the gender axiom of 'the good mother', for being indigenous, etc.) and specific drug policies' impacts that reinforce gender-based violence: the deprivation of liberty, on one hand, and reinforced stigmas towards female illicit drug users, on the other. As one of the women I interviewed expressed it: 'a male drug user is just a user; a female drug user is a user and a whore'.

According to UN Women, ${ }^{8} 35$ per cent of women worldwide have experienced either physical and/or sexual intimate partner violence or sexual violence by a non-partner (not including sexual harassment) at some point in their lives. The extreme expression of gender-based violence is the genderrelated killing of women and girls. Whereas men are victims in 80 per cent of all homicides, 82 per cent of the victims of intimate partner homicide are women (UNODC, 2018a, 11) Such gender-based killings are often the culmination of years or decades of gender-based violence. Globally, the rate of gender-based killings by family members or intimate partners-legally defined as 'femicides' or 'feminicides' and punishable as such in most Latin American countrieswas 1.3 per 100,000 of the female population in 2017 (UNODC, 2018a, 11). In 2018 in Latin America and the Caribbean, most countries had a higher rate than the global average: 6.8 in El Salvador (the highest in the region), 5.1 in Honduras, 3.4 in Trinidad and Tobago, 1.4 in Mexico, 1.3 in Ecuador, and 1.7 in Uruguay. ${ }^{9}$

\section{$3 \quad$ Gender and Drug Policy}

In this section, the gendered impacts of drug policy on women in detention are analysed.

Based on the theoretical framework of gender and patriarchal structures exposed in the first part of this chapter, the expression 'gendered impacts of drug policy' refers to two arguments: the first is that women and men involve themselves differently in drug-related activities, both in quantitative and qualitative

8 See Facts and figures: Ending violence against women published by UN Women at https:// www.unwomen.org/en/what-we-do/ending-violence-against-women/facts-and-figures (accessed on 5 May 2020).

9 See the page Feminicidio published by the Observatorio de Igaldad de Género, CEPAL at https://oig.cepal.org/es/indicadores/feminicidio (accessed on 5 May 2020). 
terms. For instance, the majority of drug users and people incarcerated for drug offences are men. Men achieve leadership status in drug trafficking organisations more often than women, and are also more likely to have a leading role in institutions that are responsible for drug demand or supply control efforts. That is, both drug policy institutions and affected populations are malerepresented and dominated. With reference to Walby's patriarchal structures (1989), both drug trafficking organisations and drug policy reproduce patriarchy by assigning women to the lowest positions in the criminal chain with little possibility of becoming leaders, and — at the same time-exploit their labour through family and partner relationships. Women's labour is thus not only expropriated and conditioned to glass ceilings, the tasks women are induced or forced to perform also put them at greater risk of being captured by law enforcement, which is reflected in the disproportionate increase in the numbers of women incarcerated for drug offences, as we shall see later in this chapter. Also, as it will be shown by women's testimonies, both women who are accused of drug offences and women who use drugs experience cyclical genderbased violence practiced against them. Whereas this is not directly provoked or incited by current drug policy, the prominence of punitive and stigmatizing discourses and practices derived by the implementation of the current drug policy framework contributes to such violence being overlooked, and-to a certain extent - to its implicit justification.

Using gender as an analytical tool to evaluate drug policy not only requires describing the participation of women and men differently, it also implies taking into account differential roles: forms of participation, ways of involvement, drugs of choice and effects of the implementation of apparently neutral regulations.

Based on the above, the second assumption that underlies the understanding of the gendered impacts of drug policy is that differential is synonymous with detrimental to women, based on transversal unequal gender relationships. That is, Héritier's 'differential valence of sexes' runs across drug trafficking, drug use and related policies.

As argued by Walby $(1989,224)$ 'the argument that the state is a patriarchal structure does not imply that the state is a monolith'. Such a statement is valid for international drug policy itself and for its application in the national context. This is why this chapter both opens and closes with remarks on womencentred positions within the mainstream drug policy narrative, which both acknowledge and attempt to tackle gender inequalities in terms of the outcomes of current drug policy. Nevertheless, this chapter argues that unless drug policy is analysed and challenged as a patriarchal structure, such proposals can only scrape the surface of inequalities and not truly resolve them. 
The next part of this chapter is structured in two sub-sections. In the first, women's accounts of their involvement in drug trafficking are presented, taking into account gender-based discrimination and violence and the intersection of patriarchal structures, along with the dynamics of the drug trade and the consequences of supply-control efforts. The last of these implies the increasing rate of female incarceration for minor, non-violent offences. In the second sub-section, women drug users' narratives are presented in relation to their life stories and the gender systems operating in drug treatment centres.

\subsection{Women in Prison for Drug Offences}

The incarceration of women for drug offences is a global phenomenon that has witnessed a staggering increase, as outlined by civil society (Álvarez, 2018, 2019a, 2019b; PRI; 2020; WOLA et al., 2016), international organisations (IACHR, 2017; INCB, 2016; UNODC, 2018b;UNWomen, 2014) and academic studies (Anderson, 2005; Bailey, 2013; Fleetwood, 2014; 2017; Giacomello, 2013a; 2017a; Maher and Hudson, 2007). It is also the main cause underlying the growth of the female prison population. Although women still constitute a significant minority in all prison systems, making up 6.9 per cent of the global prison population (Walmsley, 2017), the Institute for Criminal Policy Research's prison lists testify that the female incarceration rate has increased by 53 per cent since 2000. In comparison, general prison population growth advances at the same pace as the world population, increasing by roughly 20 per cent in the same time frame (Walmsley, 2017, 2).

As presented in UNODC's 2018 World Drug Report, women make up approximately 10 per cent of those brought in contact with the criminal justice system for drug-related offences around the world. This percentage varies, however, across regions: Oceania, Asia and Latin America have higher proportions, followed by Europe. Africa, meanwhile, has much lower numbers, with women constituting less than 5 per cent of those arrested for drug offences (UNODC, 2018b, 28).

In a report by Penal Reform International (PRI), which analyses sentencing practices in the case of women accused of drug-related offences-carried out in 18 different jurisdictions across the globe-it is demonstrated, for instance, that 'in a number of jurisdictions covered, non-custodial sentences are the more common form of sentences for low-level drug-related offences for women (for example, in England and Wales, Germany and New Zealand). In contrast, in Russia, non-custodial sentences are only issued in about $4 \%$ of drug-related offences cases' (Linklaters, 2020). In Thailand, meanwhile, 82 per cent of all women in prison are there for drug offences (Álvarez, 2019a); in the Philippines this number is 53 per cent (Álvarez, 2018). 
In Latin America, drug offences constitute, depending on the country, either the principal or the second reason for the incarceration of women (Giacomello, 2019). This results from the intersection of three factors. Firstly, Latin America is not only the most unequal region in the world and one with high levels of violence against women, but it is also a punitive one. Whereas the world incarceration rate- the number of people in prison per 100,000 of populationstands at 145 (53 per cent of countries have a lower rate), in the Americas the rate is 233 prisoners for 100,000 inhabitants, and in Central America it goes up to 316 (Walmsley, 2018). The second factor is that Latin American countries in general tend to enforce the use of prison as a response to drug offences, thus increasing the prison population. A study by the Collective of Studies on Drugs and Law (Colectivo de Estudios Drogas y Derecho, CEDD) shows that in most Latin American countries the number of people in prison for drug offences has increased much more than the general prison population and the population as a whole. In Brazil, for instance, between 2006 and 2014, the general population increased by 8 per cent, the prison population by 55 per cent and the number of people in prison for drug offences by 267 per cent. These same categories, respectively, saw increases of 19 per cent, 142 per cent and 289 per cent in Colombia between 2000 and 2015 and of 13 per cent, 49 per cent and 127 per cent in Argentina between 2002 and 2014 (Chaparro, Pérez Correa, Youngers, 2017, 26).

As shown in the study Childhood that matters (Niñez que cuenta) (Giacomello, 2019), which looks at the impact of drug policies on children with incarcerated parents in Latin America and the Caribbean, the punitive approach to the implementation of drug policies has a proportionately higher impact on women. Figure 12.1 shows the percentage of men and women incarcerated for drug offences in selected countries.

With the exceptions of the Dominican Republic and Guatemala, the differences are striking. The use of pre-trial detention and prison sentences for minor, non-violent drug offences partly explains this trend (García Castro, 2019).

The general regional trend toward incarcerating people is a direct result of international drug policies and their implementation in punitive countries. Both the 1961 Single Convention on Narcotic Drugs and the 1988 Convention against Illicit Traffic in Narcotic Drugs and Psychotropic Substances call for the use of incarceration against people who participate in drug trafficking (namely in Article 36 of the former and Article 3 of the latter). Furthermore, the number of arrests of people accused of drug offences is an indicator at the international level of successful national drug policies (Bewley-Taylor, 2016). While some margin for manoeuvre is provided in relation to dependent drug users (adding treatment or substituting it for punishment), it is not employed in most Latin 

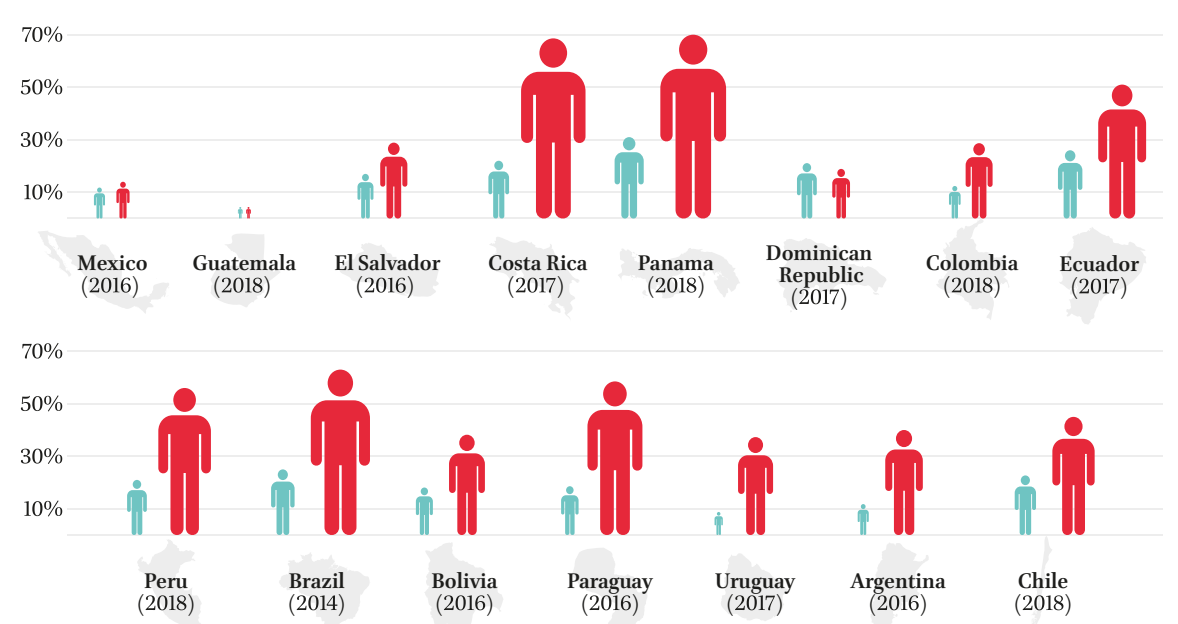

Men Women

FIGURE 12.1 People in prison for drug offences in Latin America (percentages) by sex, in selected countries SOURCE: GIACOMELLO (2019)

American countries. Furthermore, the response to micro-scale trafficking, often linked to drug dependence, is usually imprisonment or pre-trial detention. The increase in levels of incarceration, the prison crisis that affects most countries in Latin America, and the impacts of incarceration on children with incarcerated parents are therefore a direct consequence of current drug policies and their aims.

As indicated in the introduction to this chapter through the case of Gaby, what national 'success' mirrors is the continuation of an ongoing, invisible and unquestioned set of multiple forms of violence against women and girls. The following cases represent some of the women incarcerated for drug offences in Mexico. They strengthen existing knowledge with regard to incarcerated women's profiles, and to their involvement and participation in drug offences. These are often poor, uneducated women with a history of violence used against them as children and/or sexual gender-based violence used against them as women and girls, who grew up in a context of general underdevelopment and a lack of state services, in which drug trafficking organisations can proliferate. Women mainly become involved in trafficking through their male partners. Their role as agents in a context of victimisation makes the difference between consent and coercion to commit a crime more complex. Whereas most of the women I interviewed acknowledge their active participation in selling, transporting, or introducing drugs into prisons 
or trafficking them across borders, the context of their involvement conveys a 'forced choice' rather than free, willing and full consent. In addition, these complexities show the inextricable relationship between gender, violence and punishment in which agency and victimisation coexist (Giacomello, 2017a).

\subsubsection{Gaby}

As described in this chapter's introduction, Gaby was a victim of sexual violence and child-labour exploitation during her childhood. Both went unpunished. Her only appearance in official records is as a drug trafficker. During her detention, she was transferred from a mixed prison-a prison where men's facilities have a few spaces for women; either dorms, sections, or some sort of separate buildings - to Tanivet, an all-female facility closer to the state capital. It is worth pointing out that female prisoners in Mexico are mostly hosted in mixed prisons, since the country only counts 19 female prisons out of a total of 311 prison centres (CNDH, 2018). Prison conditions in Mexico are dire for everybody, but women in prison are further exposed to the violation of several rights, including the right to health, sexual and reproductive rights, the right to education, dignified living conditions, work, and sometimes the right to proximity to their families and to communication, among others. Furthermore, sexual abuse can be used as a bargaining commodity in exchange for services, and human trafficking for sexual exploitation can happen in mixed prisons as well, including the sexual abuse of children who live with their mothers. According to the National Commission on Human Rights, in 2018 there were 436 children living with their mothers in prison (CNDH, 2018). Gaby's son was no longer in Tanivet with her since she had had to face the choice of whether to keep him with her or send him to a public institution to receive rehabilitation for his conditions. At first, she asked the judge to grant her the right to accompany her son to rehabilitation and come back with him so they did not have to part. The judge, however, argued that 'children are one matter and the crime is a different one', adding that 'she should have thought about it before trafficking marijuana'. Such arguments constitute a violation of Article 9 of the Convention on the Rights of the Child, which protects the children's right to be close to their families as long as it is in their best interest. They also do not take into account the UN Rules for the Treatment of Women Prisoners and Non-custodial Measures for Women Offenders (Bangkok Rules) on applying non-custodial measures to women who are sole or primary caregivers of children (Giacomello, 2018). Gaby had to choose between her son's right to health and his right to being close to her, while both rights are interdependent and indivisible human rights (Verhellen, 2015). 
Gaby's involvement in drug trafficking began when she was a child. She was recruited by a high-ranking man in drug trafficking. Later, she was also involved with and participated in transporting marijuana because of a man, which exposed her even more to the risk of arrest. She was, as many of her prison companions, a child with limited opportunities who became a woman in a male-dominated environment, within a patriarchal state where violence against women not only goes unpunished, but is considered legitimate. The state's response, in the form of her incarceration, further violated Gaby's rights and reduced her opportunities for empowerment. It also put her son's well-being at risk: first by not providing proper living conditions and access to healthcare in prison, and then by forcing his separation from his mother as the only option if he was actually to receive treatment and rehabilitation.

Drug policy rhetoric and its system of indicators presented the stage upon, and the umbrella beneath which, state violence could be legitimately deployed. Gaby and her son are part of an official narrative of the prosecution and punishment of offenders. Such narratives must be contrasted by others that show them as victims of continued state omissions and violations, and unequal and violent gender relationships.

\subsubsection{Sonia}

Sonia's story shares common traits with Gaby's. She was accused of possession of cocaine, which translated into a five-year prison sentence. She transported the drug from Guatemala to Mexico, hidden under her skirt, travelling on a bus, with her two-year-old son on her lap and her recruiter-husband sitting beside her. The way she tells her story echoes those of most drug mules: an economic emergency — a debt incurred by her husband — which led to her husband participating as a mule in the largest world land corridor for cocaine. He then told her to travel with him: in that way, they would pay off the debt more rapidly. She refused at first, not wanting to put her family's well-being at risk, but she finally accepted. The gender axiom mandated that she obey her husband and endure the violence. She did both and simultaneously fulfilled the prescription of the good mother: she would take her youngest son with her, since it was her responsibility to look after him.

Gender prescriptions can be used to camouflage trafficking: young, beautiful women crossing borders and seducing guards, normal-looking women queuing as prison visitors, 'families' travelling together, the woman dutifully sitting by her husband (Giacomello, 2013a). In this case, Sonia's husband suggested she should hide the drug taped to her legs, under her skirt.

When arrested, they were taken to the federal police prosecution office. Officials threatened to take Sonia's son from her 'and give him to a family who 
truly loves him' Threats using children are a rather common means of psychological torture in detention, usually threatening forms of physical and sexual torture (INEGI, 2016).

The child was later sent to a public institution and both Sonia and her husband underwent pre-trial detention. He was released and she was sentenced. The lawyer convinced Sonia to plead guilty to the accusation, so her husband could be freed and go back to Guatemala with their child. Sonia has not seen her children since her imprisonment, her husband having never fulfilled his promise to visit.

Gender axioms acted to Sonia's disadvantage. Not only was she a victim of domestic violence through the prescriptions of the role of the good wife and mother, she was made to carry drugs across borders herself. She was tortured by federal police on the basis of gender axioms, then incarcerated in lieu of her husband. Such women have a name in Mexican prisons: pagadoras-payers; that is, women that do time covering up for or being accused together with, or instead of, male partners or relatives (Giacomello, 2013a).

Both Gaby and Sonia, together with dozens of incarcerated women I have spoken with over the years, share three axes that condition their agency in drug offences, since most of them acknowledge having committed an offence. The first is underdevelopment: multifactorial poverty, lack of access to basic services, little or no economic opportunities, the feminisation of poverty, and a low level of schooling. This axis is reinforced by gender discrimination and violence, which run through these women's lives and have an impact on how they become involved in drug offences, the roles they play and their exposure to being caught transporting drugs. The axis of drug policy manifests itself in two ways. First, through the creation, via prohibition, of illicit drug markets and drug trafficking organisations, which mirror hegemonic gender systems and treat women and children as disposable objects, maintaining sexist structures that lead to the exploitation of women's labour by their male partners, patriarchal relations with regard to illicit waged labour, and patriarchal violence and culture.

The other direct result of drug policy is the implementation of a punitive discourse that rests on incarceration as a means of deterrence. This has not only clearly failed, given the growth of illicit drug markets (UNODC 2019), it has two consequences that are obliterated by the rhetoric and purposes of drug policies themselves. The incarceration of poor, uneducated women who are mostly victims of violence is one such consequence. The impact of incarceration on millions of children with incarcerated parents and the creation of institutionalised, transnational children is the other (Giacomello, 2019).

Drug policy, therefore, creates the conditions for women's exploitation in a context of structural inequality, and their further exclusion through 
incarceration. Women incarcerated for drug offences are, rather than traffickers, trafficked women. The interplay of gender systems and drug policy sets the stage for the human trafficking of women by both the patriarchal state and criminal organisations. Through the current implementation of drug policy, particularly the hyper-use of the criminal justice system to the detriment of health-centred approaches, states not only fail to accomplish their mandates in terms of development and gender equality, they also generate and reinforce new and existing forms of discrimination and violence against women.

That is also the case for women who use drugs, as shown in the following section.

\subsection{Women's Drug Use and Access to Treatment}

In 20o8, the UN Office on Drugs and Crime identified five unintended consequences related to the implementation of the current international drug policy framework, which is made up of the three above-mentioned UN conventions. These consequences are: i) the creation of a criminal market; ii) 'policy displacement', meaning that more resources have been put into supply-control efforts, thus neglecting public health-oriented measures, despite the fact that public health is 'the driving concern behind drug control' (UNODC, 2008, 216); iii) geographical displacement, or the 'balloon effect', which changes production trends and trafficking routes in order to avoid law enforcement; iv) substance displacements; and, finally v) 'the way the authorities perceive and deal with the users of illicit drugs'. The UNODC continues, 'A system appears to have been created in which those who fall into the web of addiction find themselves excluded and marginalised from the social mainstream, tainted with a moral stigma, and often unable to find treatment even when motivated to seek it' (UNODC, 2008, 216).

This section is concerned with the following unintended consequences: policy displacement (ii) and how authorities deal with drug users (v).

Available information shows that, at the global level, women use illicit drugs much less than men do, while women's non-medical use of opioids and tranquillisers is at a comparable level to that of men, or higher (UNODC, 2018b, 6). Data from Latin America (CICAD, 2019) and Mexico (INEGI, 2017) confirm these trends. Gender differences with regard to drug use tend, however, to be reduced or disappear among adolescents. Women usually become involved in drug use mainly through intimate male partners, and tend to develop dependency more rapidly than men, a phenomenon known as the 'telescoping effect' (UNODC, 2018b).

According to the Council of Europe's Pompidou Group's study Improving the management of violence experienced by women who use psychoactive substanc$e s$, women drug users experience more and more severe violence than i) men, ii) women in the general population, and iii) male drug users. Also, people who 
use drugs have experienced more violence than people who do not use drugs (Benoit and Jauffret-Roustide, 2016). Women drug users are victims of i) domestic and intimate partner violence; ii) violence during childhood; iii) druguse scenes, mainly sexual violence; iv) sex work-related violence; v) human trafficking-related violence and vi) institutional violence. The latter manifests in different settings, including police stations and patrols, as well as in drug treatment centres, particularly in those shared by male and female patients.

Women's access to treatment is constrained by several factors, but the main one is the intersection of gender systems and drug policy. The lack of public health focus in drug policy not only voids the whole drug control system's supposed rhetoric and aims, it puts people's lives at risk. As stated by the Study on the impact of the world drug problem on the enjoyment of human rights from the UN High Commissioner for Human Rights (ОHCHR, 2015), current drug policies lead to several violations of drug users' human rights. These include the right to health, as policies do not guarantee access to treatment. They also criminalise drug users. In addition, people who use drugs can be victims of discrimination in healthcare settings. Lack of harm reduction services in the community and in prisons further reduces opportunities to reach drug users and to reduce the transmission of HIV and hepatitis B and C, or to prevent overdoses. Stigma and criminalisation around drug use discourage users from looking for support in the healthcare sector, for fear of being arrested. SDG number 3, 'Ensure healthy lives and promote well-being for all at all ages', (UN General Assembly, 2015, 14) specifically addresses these issues in targets 3.3 (by 2030, end the epidemics of AIDS, tuberculosis, malaria and neglected tropical diseases and combat hepatitis, water-borne diseases and other communicable diseases) and 3.5 (strengthen the prevention and treatment of substance abuse, including narcotic drug abuse and harmful use of alcohol).

Lack of sufficient treatment facilities, on the one hand, and barriers to access to existing treatments, on the other, both result directly from drug policy in specific national settings. Both are worse for women. According to the International Narcotics Control Board, 'fewer women than men who need to access treatment are able to do so' (INCB, 2016, 8). This is directly related to cultural, social and structural barriers in which drug policy and gender interweave:

Globally, women make up one third of people who abuse drugs, but just one fifth of those who are in treatment. Women encounter significant systemic, structural, social, cultural and personal barriers to accessing substance abuse treatment. At the structural level, the main obstacles include a lack of childcare services and judgmental attitudes to women who abuse drugs, especially if they are pregnant. Often, residential 
treatment programmes do not admit women with children. Women who use drugs may not seek treatment for fear of losing custody of their children. Other reasons for low uptake of treatment by women include hostile attitudes of medical staff or clinics being inundated with male clients, making them uninviting for female clients.

INCB, 2016, 7

Women also face greater barriers to accessing harm reduction services and treatment in prison (Sander, Shirley-Beavan and Stone, 2019) and in the community. This is not exclusive to Latin America but can be defined as a global problem, with different countries providing different levels and quality of access (Ayon et al., 2019; Médecins du Monde, 2019; Uusküla et al., 2018); furthermore, women who use drugs and are victims of violence are usually denied access to shelters for women victims of violence based on their drug use, either by law or by institutionalised practice, thus leaving them and their children in a situation of further vulnerability due to the actions of state and private institutions (Benoit and Jauffret-Roustide, 2016; HRI, 2013).

\section{$3 \cdot 3$} Women in Drug Treatment Centres in Mexico

In Mexico, public drug treatment facilities are scarce: only 44 residential centres, plus 11 facilities operated by Centres of Juvenile Integration (Centros de Integración Juvenil (CIJ s) - a government-funded civil organisation) versus an estimated 2,108 private centres (CONADIC, 2019a). Only half of the private centres are registered with the National Commission against Addictions (Comisión Nacional contra las Adicciones, CoNADIC), which is, among other functions, the authority responsible for the monitoring of drug treatment centres. Of the 1,045 registered centres, only 348 are recognised by CONADIC, which means that they have been evaluated and supervised. Of these, 99 are for men and women, 34 for women only and the rest for men only (CONADIC, $2019 \mathrm{~b}$ ). CIJ s are also mixed. As in the case of prisons, therefore, women are mostly treated in mixed centres. The sizeable dominance of unregistered and unsupervised residential treatment centres translates into a myriad of methods, living conditions, and often abuses. Most centres, colloquially known as 'barns' (granjas) or 'annexes' (anexos) are places where physical punishment is common, together with psychological ill treatment, forced labour, sexual abuse and killing. For drug users forced to live in these centres indefinitely, not waking up the next day is a concrete threat. Unfortunately, academic research on this topic is scarce, as venturing into these centres is risky.

As explained in the introduction to this chapter, the following pages are based on field work carried out between February and November 2019 as part 
of an ongoing research project that the author is developing for the University of Chiapas and EQUIS Justice for Women (Mexico). Table 12.1 shows how the interviews are distributed.

The interviews with women and girls were carried out individually or in groups, depending on the women's choice. Both in prison and treatment centres, privacy was guaranteed and the conversations took place in confidential settings. The interviews centred on two main topics: the development of dependent drug use in relation to interviewees' life stories, and interviewees' experiences in residential treatment. Figure 12.2 shows the information gathered for each woman or girl. It systematises the information on 21 women and 4 girls in drug treatment centres, 15 women in prison and 2 former drug users who work, respectively, as director and sub-director at private treatment centres.

The first two columns indicate name and age; in the next nine-colouredcolumns the first drug used is marked with the interviewee's age at first use (either with the specific age or with an age range or time period; see the figure's key for details). Where two or more drugs were used for the first time at the same age range, the additional substances are referred to in the same way. 'ATs s' stands for amphetamine-type stimulants. The next-monochrome-column reports whether the woman or girl has been a victim of sexual abuse. This question was never formulated specifically, the topic only being brought up by the author if conditions of confidence had been established or by the interviewees themselves. Therefore, when sexual abuse was not discussed, the case is labelled 'not specified' in grey colour. If there is no sign, it indicates that the woman or girl specifically affirmed that they had not been raped. The final column records the number of children, with pregnancy at the time of interview denoted by an asterisk.

TABLE 12.1 Type and number of informants

\section{Group}

Number of interviews

Women in drug treatment centres

21

Girls in drug treatment centres 4

Boys in drug treatment centres 4

Women in prison

Women in prison for drug offences (no drug use)

People with academic or professional knowledge

on this topic 
A. Women in drug treatment centres

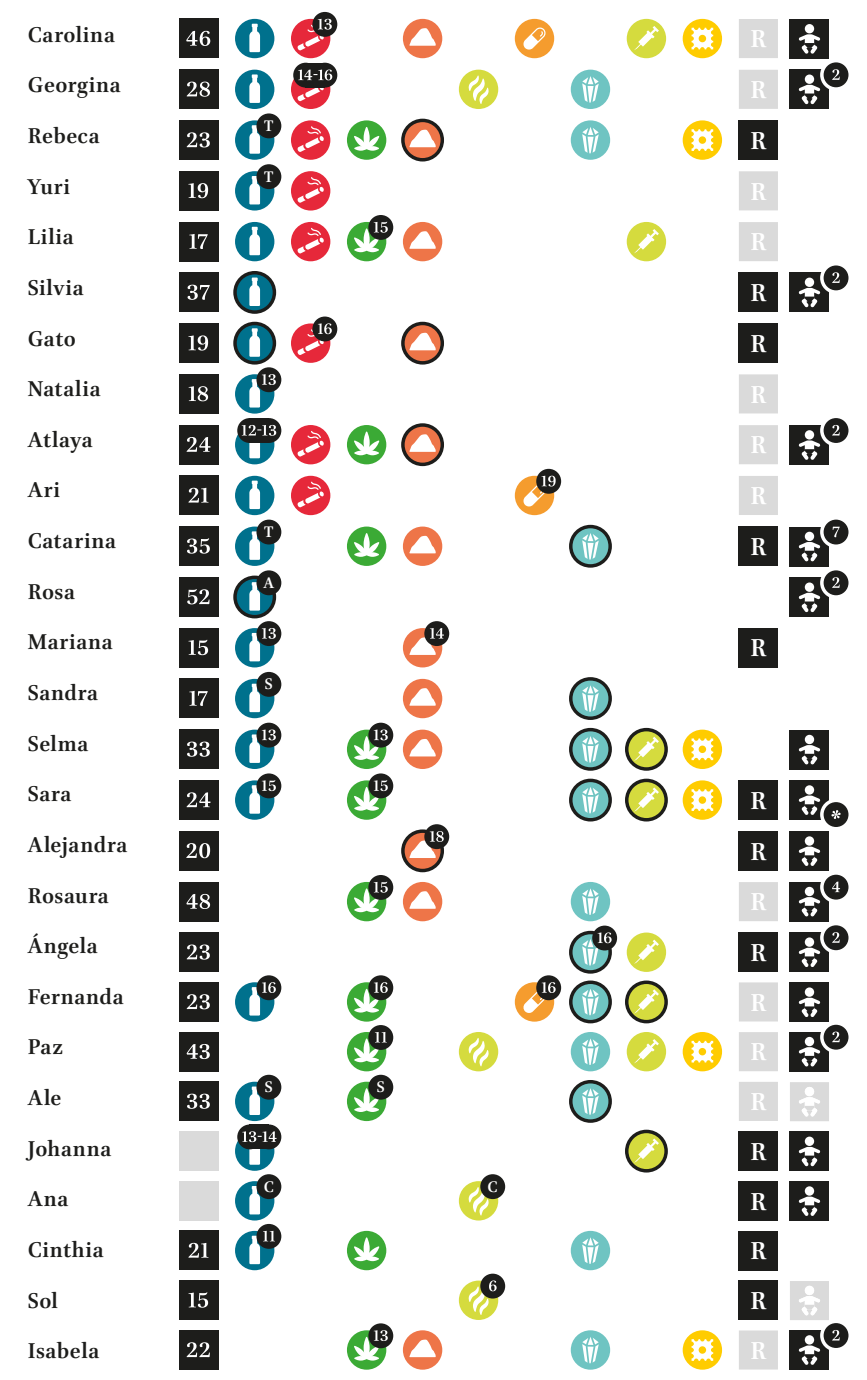

FIGURE 12.2 Information gathered on women and girls who use drugs SOURCE: CREATED BY AUTHOR

In terms of drug use, the data reflect national trends, with alcohol and tobacco being the first drugs used and marijuana the first illegal one (Instituto Nacional de Psiquiatría Ramón de la Fuente Muñiz, 2017). Drugs of impactthat is, those that cause more individual and social harm-are mainly crystal meth, heroin and cocaine-type drugs. All drug use, with one exception, begins in childhood (the lowest ages being six and nine) and adolescence. Family 


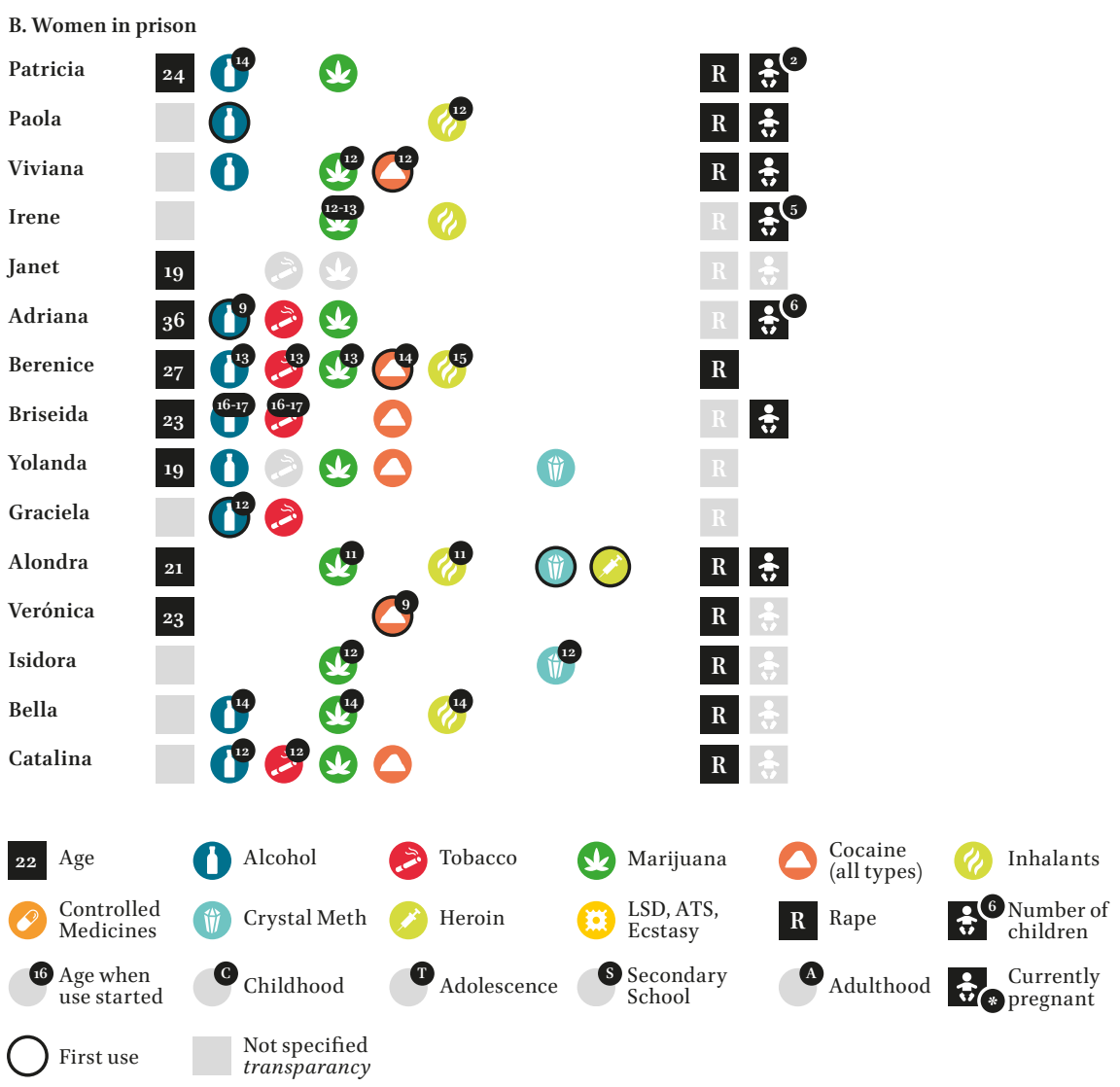

FIGURE 12.2 Information gathered on women and girls who use drugs (cont.)

members (mainly fathers and brothers) are the main vector of introduction to drug use. For example, Marta was given cocaine by her father, a federal police officer, when she was 12, so that 'no one could fool her when she grew up'. Most women have families with precedents of alcohol abuse.

Of the 43 women and girls, 21 reported sexual abuse. The main perpetrators were uncles, stepfathers, fathers, grandparents and cousins. A total of 23 had children, reflecting the trend of teenage pregnancies mentioned in this chapter's introduction. That was the experience of Sarah, who was abused by her older cousins when she was eight and until she was 11, every Sunday afternoon, right after mass. Or Tamara, who was abused by her grandfather and then sent to a juvenile detention centre after she stabbed him to death at the age of 16. 'Cat' (Gato) was raped by her grandfather beginning when she was three years old and then by her father at the age of 16 . Sexual violence is 
not usually reported, and when it is female children are usually not believed. None of the multiple forms of violence these women suffered as children led to consequences for the perpetrators. They did, though, for their victims. These women's relationships with drugs are intrinsically related to their life stories and gender (Romero Mendoza et al., 2018).

The following cases provide an example of the narratives that shape the findings of the research presented here. The first is the case of Alejandra, an incarcerated women at the time of the interview. The second is that of Sol, a young adolescent who worked as a killer for a drug cartel and was detained against her will in a private treatment centre.

\subsubsection{Alejandra}

'You have had a very difficult life ...', I state, after more than 40 minutes of listening to her, feeling that a piece was missing. 'After a situation that happened to me ... I changed. I was happy ...' she says looking down, 'I was happy, happy ...' she reaffirms, her mind recollecting memories from a time in her childhood. 'Did someone hurt you?' I ask. Her story finally begins.

Alejandra (Ale) was thirteen and she lived in a village in Chiapas, a poor state in the south of Mexico. She lived with her grandparents and her siblings. Both her parents lived in other Mexican states. One morning she was walking to school. She usually walked with a schoolmate, her platonic love. But that day he did not show up. Two neighbours appeared. They hit her ankles with a stick and forced her to walk with them to a nearby field. She called for help, but nobody came. 'They did everything they wanted with me', she said, raping and beating her for hours. When they let her go, they urged her not to tell anybody and threatened to rape her sisters if she did. They started standing in front of her house every day, checking on her, forcing her into fearful silence. After a few days, she shared what happened with her grandmother. Yet even after her family told the police, nothing happened. She went back to school a few days after that, changing the way she went back home, trying to avoid them. But one day the same two men intercepted her. They took her to a house and kept her captive, raping and beating her. 'There were kids in the room', she said, perhaps the men's sons or nephews, and they would say to them: 'Look and learn how to treat women'. After three days, they released her.

That was the story that changed Ale's life. Her adolescence and youth were marked by drug abuse and detention in a juvenile penal centre. She was accused of being an accomplice in a homicide, and turned to prostitution to obtain money to pay for drugs. Yet she needed more drugs to find the strength to sell herself again. When I met her, she was in pre-trial detention in the female section of the medium-security prison El Amate, being held for robbery with violence. 


\subsubsection{Sol}

Sol was 15 years old when I interviewed her. She was kept in an 'anexo'. Her family brought her there by force and she was dragged inside, with violence, by the anexo's 'guards' (inmates who acquire some degree of authority within the centres' vertical regime of control). She feared for her life: on the one hand, Fito, a 'military man' or 'former police man' in charge of the centre's securityas the women and girls I spoke to described him — could punish her and her fellow inmates for giving an interview. On the other, she knew that the drug cartel she used to work for might attempt to murder her: 'I left the cartel; there is no way out of the cartel, only death'.

Her drug use began when she was six, with inhalants. She grew up in the red zone of a city in northern central Mexico, with her mother, a sex worker. Then her mother moved to Tijuana, on the northern border, where she started working as a 'company lady' for a drug cartel. Sol's father worked for a rival drug cartel on the other side of the border, in Ciudad Juárez. Sol was raped by her stepfather when she was four and then again, at the age of eight, by her mother's boss. He forcibly enrolled Sol to sell drugs, hire other women for the cartel and, later, to become a hitwoman, a sicaria.

Both Alejandra and Sol, and most of the women and girls I spoke to, shared a common life experience that can be summarised as follows: first, as children, violence is perpetrated against them within their family, mainly in the form of sexual and physical violence, neglect, and verbal violence. When they attempt to share details of these episodes of sexual violence they are not believed; on the contrary, they are accused of being liars or blamed for provoking their stepfathers or other male perpetrators. Other reactions-usually from their mothers - include battery. Two main scenarios develop before them: becoming involved in a cycle of gender-based violence in the context of relationships with older men, drug-use settings, and institutional settings (police stations, prisons and drug treatment centres); this usually leads to multiple pregnancies - as teenagers first and adult women later — and, sometimes, sex work, partner-induced sex exploitation and crime. They might also end up living on the street. In either case, fleeing from violence opens up new means of abuse.

In those cases in which they are forcibly enrolled by organised crime, the hitwomen I spoke to-four of them in prison and two girls in a drug treatment centre-experienced this in early adolescence. By the time I spoke to them, they all had been victims of multiple rapes and had killed uncountable numbers of people. When asked about the role of the state, incarcerated women's opinion was clear and definite: 'The State only beats us, arrests us and kills us'. 
During the first part of the interviewees' narratives, drugs are clearly a coping mechanism against the pain caused by neglect and abuse in the household and in intimate partner relationships. When dependence develops and life starts revolving around drugs, their reference points — mainly family — fall apart and riskier situations occur, such as living on the street, sex work and exposure to criminalisation and incarceration. At this point, compulsory treatment comes into play, and women, once again, as in the case of women incarcerated for drug offences, are isolated in male-dominated spaces where plural forms of gender-based violence against women take place. Patriarchal structuresnamely violence against women, and patriarchal culture-reproduce themselves in drug-using circuits as well as in treatment centres.

The treatment centre where I interviewed Sol was particularly dangerous and I was prompted to leave by the owner, allegedly a protestant pastor, as already mentioned in the introduction to this chapter. As happens in other treatment centres, people were held there compulsorily for an indeterminate length of time. Selma, for instance, was held in a drug treatment centre for a full year without ever setting foot outside. It is a very gloomy, smoky place, too small for all the people living in it, with no ventilation or natural light. Because of her good conduct and achievements with regard to her treatment, she was allowed to go home to visit her young daughter. She went to the United States, near the border with Mexico, where her family lived. There she met her cousin, with whom she used to smoke methamphetamine before going into treatment. She smoked again. Despite the fact that she was reunited with her daughter, and that she had used the drug again, she dutifully returned to the drug treatment centre. Selma's return to the centre should have been seen as a major accomplishment in her recovery. The centre, however, found out that she had relapsed, and relapsing is considered a condition of drug dependence. So she was sanctioned: she had to sit for weeks on the 'bench of the relapsing users', on display for the entire centre. This happened four months before I interviewed her in August 2019. She explained to me that her relapse implied that her previous record of treatment had all but never existed. 'I have to accept that I have been here for four months, not one year and four months'.

It is important to stress that this centre is certified by the public national authority. People are held there indefinitely. The length of the treatment is decided by the owners themselves based on an arbitrary evaluation of the process of recovery, while aiming for abstinence. Patients-usually referred to as 'inmates' - are generally brought there by their families against their will and left in the hands of the owners, who isolate and make a living out of a secluded population of drug users on an obligatory path to abstinence. In other 
cases, drug users are picked up — practically kidnapped — by a centre's staff and forced into vehicles to be transported to the centre. Such 'collectors' are known as 'the Celestial Patrol'. Personally, after interviewing Selma I felt an urgent need to escape. Never had I felt such a sense of imprisonment, not even in the top security section of a female federal prison.

Besides sexual violence, which does not seem to occur in the centres I visited, other forms of gender-based violence and discrimination affect women, especially in mixed centres. These can be divided into three forms: discursive, structural, and normative.

Discursive gender-based violence is reflected in how a centre's personnel refer to women who use drugs: more problematic than men, trying to attract men's attention for sexual purposes, individually responsible for drug dependence and its consequences. Girls and women are guilty of their drug consumption, structural conditions being completely dismissed and unaccounted for in the dependence diagnosis. Drug use is seen as an individual problem that people must resolve themselves through treatment and seclusion, aiming for abstinence. This discourse is applied to men as well; in the case of women, however, 'personal failure' is reinforced by the transgression of gender axioms. Women users are doubly labelled and stigmatised, facing even further discrimination when they are mothers.

Such discourses are entrenched in structural and normative conditions. In structural terms, mixed centres have fewer places for women. For instance, in one of the public centres I visited, out of a total of 40 beds, only six were assigned to women. The assumption that women use drugs less than men is not a sustainable justification for this disparity, since among adolescents the gender difference is almost inexistent. Also, given the barriers that women face to accessing treatment, lack of spaces can translate into exclusion, and therefore into pushing women away from healthcare rather than convincing them to seek help.

Patriarchal structures are reproduced in treatment centres' gender systems. For example, in a mixed treatment centre in Baja, California, the director, a former drug user himself, had married one of the female inmates, who is now sub-director. Women in mixed centres often need to find themselves what I define as 'a dominant male' to make them their property, so that other users or staff do not try to openly sexually objectify them. In horizontal relationships among competing masculinities and their interaction with vertical patriarchal sexual domination over women, women are forced to 'choose' a sexual partner that will take them out of the realm of 'disposable sexual object' to the legitimate place of 'woman of someone'. This is also pointed out in the Pompidou Group's report: 
The relations between women users, men users and the staff of these communities reproduce relations in the outside world: women are often stigmatised and harassed by certain male users, but also by some members of staff. Any friendly gesture on the part of the women may be perceived as an attempt to seduce. If they flirt, women are also judged and found guilty because of the deeply ingrained notion that they are using their bodies to get drugs in exchange. This sometimes leads women to accept, as they did before taking up residence, a relationship based on a protection strategy, to avoid harassment and violence on the part of other male residents and the staff of the centre.

BENOIT and JAUFFRET-ROUSTIDE, 2016, 25

In that same centre in Baja, while men were allowed to go out to carry out 'services' for the centre-basically collecting money in the street or working for free in bakeries and other similar establishments or warehouses-women could never leave the centre. The reason given was that women had to be 'protected', mainly from themselves, since they were believed to sexualise themselves to seduce men.

Gender discrimination beliefs detrimental to women are reproduced in other practices. In two public mixed treatment centres I visited, men and women can have no contact with one another and have to follow clothing regulations that do not provoke sexual behaviours. For example, women cannot wear shorts, skirts or dresses. When verbal, written or oral interchanges happen between men and women, women are usually accused of inciting the men. One female patient told me that on one occasion she left her dorm in the middle to the night to go to the toilet and that she was wearing tight leggings. The day after, she received a warning and was told, 'You are trying to get yourself raped'. This woman had been a victim of sexual abuse since she was three years old.

Empirical research, together with the wider framework of gender systems, drug policy and women's barriers to accessing treatment, support the argument that in the case of female drug users and in addition to discursive and practical elements, current drug policies are inscribed in patriarchal structures that create conditions for, and the justification of, gender-based violence, domestic violence and violence against women and girls. The two groups of 'women in detention' analysed in this chapter, instead of being accompanied by communities, families and state institutions that are supposed to address and attempt to repair the suffering and the crimes committed against them, are further isolated through institutionalisation on legal or illegal sites, in which violence against women is further reproduced. 


\section{Conclusions}

This chapter has focused on two groups of women in detention: incarcerated women and women in residential drug treatment centres. It has analysed, within the theoretical framework of gender, how gender, development and drug policy intersect. It has argued that the current system of drug control is part and parcel of patriarchal structures and that the interplay of drug policy and gender systems that are detrimental to women establishes the conditions for gender-based violence against women and girls. It does so by promoting the prosecution and incarceration of people accused of non-violent, minor drug offences, and by a discursive and practical framework of the stigmatisation and criminalisation of people who use drugs. Drug policy creates a platform for the trafficking and sexual and labour exploitation of women and children, in their families and communities, as well as by organised crime and state institutions. By fostering a system of law enforcement to the detriment of a public health approach, current drug policies have unleashed a human rights crisis that mainly affects disadvantaged populations in developing countries and drug users. Interwoven with gender systems based on the 'differential valence of sexes' as discussed above, disparities manifest themselves in the feminisation of poverty and violence against women. Both elements are underlying causes of women's involvement in drug offences and dependent drug use, and hinder development and women's empowerment, as well as the achievement of gender equality.

The international drug policy arena has taken notice of these issues in recent years. UNODC has produced material on women and drug use and dedicated a booklet to women in the 2018 World Drug Report (UNODC, 2018b). The International Narcotics Control Board (INCB, 2016) has dedicated a special chapter in one of its annual reports to women's participation in drug offences and drug use.

As introduced at the beginning of this chapter, in preparation for the UN Special General Assembly on Drugs in 2016 (UN General Assembly, 2016), UN Women (2014) submitted the policy brief A Gender Perspective on the Impact of Drug Use, the Drug Trade, and Drug Control Regimes. In it, the organisation affirms that 'apart from a more humane and balanced approach to international drug control efforts, centered on human rights and emphasizing the public health dimensions of this crisis, this approach must also be gender-responsive' (UN Women, 2014, 3).

In March 2016, the Commission on Narcotic Drugs approved the resolution Mainstreaming a Gender Perspective in Drug-related Policies and Programmes (UN CND, 2016). Despite the existence of the two previous resolutions on women, this one distinguishes itself by being integral in its approach. The text 
recognises women as users and points out barriers to access to treatment. It also stresses women's involvement in trafficking - mainly in the lowest positions of criminal organisations and often occurring through deceit and coercion-and highlights the importance of women as agents in drug policy, calling for women's active involvement in 'the development and implementation of national drug-related policies and programmes' (UN CND, 2O16, 3). Among other actions proposed by the resolution are i) to collect and share quantitative and qualitative data, disaggregated by age and sex, related to the world drug problem; ii) to prefer non-custodial measures when sentencing or deciding on pre-trial measures for a pregnant woman or a woman who is a child's sole or primary carer; and iii) 'to increase the coverage of existing programmes and to ensure access to those programmes while providing training and supervision for all relevant health and social care professionals working with women, including in prison settings' (UN CND, 2016, 4).

Also, in the final document of the UN General Assembly (2016), there is a specific reference to mainstreaming gender perspectives:

Mainstream a gender perspective into and ensure the involvement of women in all stages of the development, implementation, monitoring and evaluation of drug policies and programmes, develop and disseminate gender-sensitive and age-appropriate measures that take into account the specific needs and circumstances faced by women and girls with regard to the world drug problem and, as States parties, implement the Convention on the Elimination of All Forms of Discrimination against Women.

UN General Assembly, 2016, 15

Such calls are meaningful and necessary. Collecting sex-disaggregated data, promoting the use of alternatives to incarceration for women who are pregnant or primary caregivers, improving and broadening women's access to treatment and including affected women in drug policy's design, implementation and evaluation are all fundamental steps that should be encouraged. However, they will only have a cosmetic impact if they are not part of a wider spectrum of urgently needed transformations in the international system of drug control and its implementation, rhetoric, indicators and practices. A 'deep evaluation'10

10 Bacchi develops the methodology of deep evaluation as an ex ante policy analysis that consists of developing 'a form of policy evaluation that encourages critical scrutiny of conceptual premises, models of implementation and conventional forms of evaluation within a proposed or existing policy' (Bacchi and Eveline, 2010, 16). 
(Bacchi and Eveline, 2010) should replace the current practice of gender analysis in drug policy, to ensure the transformative power of gender mainstreaming and to eradicate the reproduction of patriarchal structures. Such an approach should start at the core of the international system of drug control and its institutions, which should lead the way for nations to undertake the same paths.

Furthermore, it is paramount that women who use drugs, drug use communities, professionals, and civil society organisations working on related issues, foster and become part of alternative, stigma-free, empowerment-oriented narratives and practices around gender, the use of drugs, women's needs and strengths, gender-based violence, and caring responsibilities. The active participation of women who use drugs is not only ethically desirable, it is indispensable to the development of tools that i) effectively respond to the diverse situations of women and drug use, ii) address women's needs, and iii) acknowledge and build on their strengths, providing orientation, strategies and practices for women who use drugs in general, with an intersectional approach.

Given the current status of violence against women and structural inequalities in most developing countries, it is obvious that current drug policy is not the only or even the main cause of violence against women and girls and that even deep changes in the way the drug conventions are implemented would not tackle background gender systems. If, however, gender inequality is not addressed properly by the international system of drug control as part of a 'scrutiny from within', drug policy will remain a strong component of patriarchal structures, and a handy rhetoric and practical tool to reproduce women's symbolic and concrete detention.

\section{References}

Álvarez, M.C.A. (2019a) Women, Drug Policy and Incarceration in Thailand: Promoting Humane and Effective Responses (London: International Drug Policy Consortium), http://fileserver.idpc.net/library/Thailand_Policy_Guide_Women.pdf (accessed on 8 October 2019).

Álvarez, M.C.A. (2019b) Women, Drug Policy and Incarceration in Indonesia: Promoting Humane and Effective Responses (London: International Drug Policy Consortium), http://fileserver.idpc.net/library/Indonesia_Policy_Guide_Women.pdf (accessed on 8 October 2019).

Álvarez, M.C.A. (2018) Women, Drug Policies and Incarceration in the Philippines: Promoting Humane and Effective Responses (London: International Drug Policy Consortium), http://fileserver.idpc.net/library/Philippines_Policy_Guide_Women.pdf (accessed on 8 October 2019). 
Anderson, T.L. (2005) 'Dimensions of women's power in the illicit drug economy', Theoretical Criminology, 9(4), pp. 371-40o.

Ayon, S., F. Jeneby, F. Hamid, A. Badhrus, T. Abdularham and G. Mburu (2019) 'Developing integrated community-based HIV prevention, harm reduction, and sexual and reproductive health services for women who inject drugs', Reproductive Health, 16(1), DOI: 10.1186/s12978-019-0711-z.

Bacchi, C. and J. Eveline (2010) Mainstreaming politics: Gendering practices and feminist theory (Adelaide: University of Adelaide Press), https://digital.library.adelaide.edu.au/dspace/bitstream/2440/64322/2/hdl_64322.pdf (accessed on 1 December 2019).

Bailey, C. (2013) 'Exploring Female Motivations for Drug Smuggling on the Island of Barbados: Evidence from Her Majesty's Prison, Barbados', Feminist Criminology, 8(2), pp. 117-141.

Benoit, T. and M. Jauffret-Roustide (2016) Improving the management of violence experienced by women who use psychoactive substances (Strasbourg: Council of Europe), https://rm.coe.int/improving-the-management-of-violence-experienced-by-women-who-use-psyc/168075bf22 (accessed on 7 October 2019).

Bewley-Taylor, D. (2016) 'Towards Metrics that Measure Outcomes that Matter' (Swansea, UK: Global Drug Policy Observatory and Swansea University), https://www. swansea.ac.uk/media/Towards-Metrics-that-Measure-Outcomes-that-Matter.pdf (accessed on 7 October 2019).

Chaparro, S., C. Pérez Correa and C. Youngers (2017) Castigos irracionales: leyes de drogas yencarcelamiento en América Latina (Mexico City: Colectivo de Estudios Drogas y Derecho), http://fileserver.idpc.net/library/Castigos_Irracionales.pdf (accessed on 8 October 2019).

CiCAD (Inter-American Drug Abuse Control Commission) (2019) Report on Drug Use in the Americas 2019 (Washington D.C.: Organization of American States), http:// www.cicad.oas.org/main/pubs/Report\%20on\%2oDrug\%2oUse\%2oin\%2othe\%2O Americas\%202019.pdf (accessed on 8 October 2019).

CNDH (Comisión Nacional de los Derechos Humanos) (2018) Diagnóstico Nacional de Supervisión Penitenciaria 2018 (Mexico City: Comisión Nacional de los Derechos Humanos), https://www.cndh.org.mx/sites/all/doc/sistemas/DNSP/DNSP_2018.pdf (accessed on 8 October 2019).

CONADIC (Comisión Nacional contra las Adicciones) (2019a) Informe sobre la situación del consumo de drogas en México y su atención integral 2019 (Mexico City: Gobierno de México, Secretaría de Salud and Comisión Nacional contra las Adicciones), https://www.gob.mx/cms/uploads/attachment/file/477564/Informe_sobre_la_situacio_n_de_las_drogas_en_Me_xico_.pdf (accessed on 8 October 2019).

CONADic (2019b) Directorio de Establecimientos Residenciales de Atención a las Adicciones Reconocidos zer Trimestre 2019 (Mexico City: Comisión Nacional contra las 
Adicciones), https://datos.gob.mx/busca/dataset/directorio-de-establecimientosresidenciales-de-atencion-a-las-adicciones-reconocidos/resource/8f9954ed-732e4d55-bo73-59b57ede97d6?inner_span=True (accessed on 8 October 2019).

Council of Europe (2011) Council of Europe Convention on preventing and combating violence against women and domestic violence (Istanbul: Council of Europe), https:// rm.coe.int/168046o31c (accessed on 7 October 2019).

ECLAC (Economic Commission for Latin America and the Caribbean) (2019) Quadrennial report on regional progress and challenges in relation to the 2030 Agenda for Sustainable Development in Latin America and the Caribbean (Santiago, Chile: United Nations), https://repositorio.cepal.org/bitstream/handle/11362/44552/7/S19oo432_ en.pdf (accessed on 7 October 2019).

Fleetwood, J. (2017) 'Introduction: Drug Mules: International Advances in Research and Policy', The Howard Journal of Crime and Justice, 56(3), pp. 279-287.

Fleetwood, J. (2014) Drug Mules. Women in the International Cocaine Trade (London: Palgrave Macmillan).

García Castro, T. (2019) Prisión preventiva en América Latina: el impacto desproporcionado en mujeres privadas de libertad por delitos de drogas (Washington D.C.: Washington Office on Latin America) https://www.wola.org/wp-content/uploads/2019/ o5/Prisi\%C3\%B3n-Preventiva-en-America-Latina_Junio-2019.pdf (accessed on 24 March 2O2O).

Giacomello, C. (2019) Niñez que cuenta. El impacto de las políticas de drogas sobre niñas, niños y adolescentes con madres y padres encarcelados en América Latina y el Caribe (Buenos Aires: Church World Service Regional Office), http://www.cwslac.org/nnapespdd/docs/Estudio-Regional-Ninez-que-cuenta-web.pdf (accessed on 8 October 2019).

Giacomello, C. (2018) Niñas y niños que viven en prisión con sus madres. Una perspectiva jurídica comparada (Mexico City: Suprema Corte de Justicia de la Nación), https:// www.scjn.gob.mx/derechos-humanos/publicaciones/libros/fb/o5-ninas-ninos-viven-prision-madres/II/ (accessed on 8 October 2019).

Giacomello, C. (2017a) 'Women and Drug Policies in Latin America: A Critical Review of the United Nations Resolution 'Mainstreaming a Gender Perspective in Drug-Related Policies and Programmes', The Howard Journal, 56(3), pp. 288-308.

Giacomello, C. (2017b) 'Mujeres privadas de la libertad: una perspectiva sobre derechos y género en la ejecución penal' in J. Di Corleto (ed) Género y justicia penal (Buenos Aires: Ediciones Didot).

Giacomello, C. (2013a) Género, drogas y prisión. Experiencias de mujeres privadas de su libertad en México (Mexico City: Tirant Lo Blanch).

Giacomello, C. (2013b) Mujeres, delitos de drogas y sistemas penitenciarios en América Latina (London: International Drug Policy Consortium), https://www.unodc. org/documents/congress/background-information/ngo/idpc/idpc-Briefing-Paper_ Women-in-Latin-America_SPANISH.pdf (accessed on 8 October 2019). 
Giacomello, C., I. Erreguerena and I. Blas (2017) Políticas de drogas, género y encarcelamiento en México. Una guía para políticas públicas incluyentes (Mexico City: Equis, Justicia para las Mujeres), http://equis.org.mx/wp-content/uploads/2018/o2/ Gui\%CC\%81a_Drogas.pdf (accessed on October 8 2019).

Goffman, E. (1961) Asylum. Essays on the Social Situation of Mental Patients and Other Inmates (New York: Anchor Books).

Héritier, F. (2007) Masculino / Femenino II. Disolver la Jerarquía (Buenos Aires: Fondo de Cultura Económica) [Translation from (2002), Masculin / féminin II. Dissoudre la hiérarchie (Paris: Odile Jacob)].

HRI (Harm Reduction International) (2013) Briefing paper on Violence against Women who use Drugs and Access to Domestic Violence Shelters (London: HRI), https://www. hri.global/files/2013/o3/19/Briefing_Paper_-_Access_to_Shelters_-_with _correct_ fonts_07.03_.13_pdf (Accessed on 27 March 2020).

IACHR (Inter-American Commission on Human Rights) (2017) Medidas para reducir la prisión preventiva (Washington D.C.: Organization of American States), http://www. oas.org/es/cidh/informes/pdfs/PrisionPreventiva.pdf (accessed on 8 October 2019).

IACHR (2008) Principles and Best Practices on the Protection of Persons Deprived of their Liberty in the Americas (Washington D.C.: Organization of American States), https:// www.oas.org/en/iachr/mandate/Basics/principles-best-practices-protectionpersons-deprived-liberty-americas.pdf (accessed on 7 October 2019).

ILO (International Labour Office) (1999) Worst Form of ChilLabour Convention, 1999 (No. 182) (Geneva: ILO), https://www.ilo.org/wcmsp5/groups/public/---ed_norm/---declaration/ documents/publication/wcms_decl_fs_46_en.pdf (accessed on 7 October 2019).

INCB (International Narcotics Control Board) (2016) Annual Report 2016 (Vienna: INCB), https://www.incb.org/documents/Publications/AnnualReports/AR2016/ English/AR2016_E_ebook.pdf (accessed on 8 October 2019).

INEGI (Instituto Nacional de Estadística y Geografía) (2017) Encuesta Nacional de Consumo de Drogas, Alcohol y Tabaco, ENCODAT 2016-2017 (Mexico City: Instituto Nacional de Estadística y Geografía), https://www.gob.mx/salud\%7Cconadic/ acciones-y-programas/encuesta-nacional-de-consumo-de-drogas-alcohol-ytabaco-encodat-2016-2017-136758 (accessed on 8 October 2019).

INE g ( 2016) Encuesta Nacional de Población Privada de la Libertad (ENPOL) 2016 (Mexico City: Instituto Nacional de Estadística y Geografía), https://www.inegi.org.mx/ programas/enpol/2016/ (accessed on 8 October 2019).

Instituto Nacional de Psiquiatría Ramón de la Fuente Muñiz (2017) Encuesta Nacional de Consumo de Drogas, Alcoholy Tabaco, ENCODAT 2016-2017 (Mexico City: Instituto Nacional de Psiquiatría Ramón de la Fuente Muñiz), https://encuestas.insp.mx/ ena/encodat2017.php (accessed on 27 March 2020).

Lenzer, G. (2015) 'Violence against children', in W. Vandenhole, E. Desmet, D. Reynaert and S. Lembrechts (eds), Routledge International Handbook of Children's 
Rights Studies (New York and London: Routledge Taylor \& Francis Group), pp. 276-294.

Linkaters (2020) Sentencing of women convicted of drug-related offences (London: Linklaters, Penal Reform International, Drug Policy Consortium), https://cdn.penalreform.org/wp-content/uploads/2020/o2/LinklatersPRI_Sentencing-of-womenconvicted-of-drug-related-offences_WEB.pdf (accessed on 24 March 2020).

Maher, L. and S.L. Hudson (2007) 'Women in the drug economy: a metasynthesis of the qualitative literature', Journal of Drug Issues, 37, pp. 805-26.

Médecins du Monde (2019) HIV and other sexually transmitted infections among female sex workers in Moscow (Russia). Prevalence and associated riskfactors (Paris: Médecins du Monde) https:/www.medecinsdumonde.org/en/file/147510/download?token $=\mathrm{oReOF}_{5}$ le (accessed on 27 April 2020).

OHCHR (Office of the High Commissioner on Human Rights) (2015) Study on the impact of the world drug problem on the enjoyment of human rights (Geneva: United Nations), http://www.ohchr.org/EN/HRBodies/HRC/RegularSessions/Session3o/Documents/ A_HRC_3O_65_E.docx (accessed on 8 October 2019).

о HС R (2014) Sexual and gender-based violence in the context of transitional justice (Geneva: United Nations), https://www.ohchr.org/Documents/Issues/Women/ WRGS/OnePagers/Sexual_and_gender-based_violence.pdf (accessed on 7 October 2019).

PAHO (Pan-American Health Organization) (2017) Accelerating progress toward the reduction of adolescent pregnancy in Latin America and the Caribbean (Washington D.C.: PAHO, United Nations Population Fund and United Nations Children's Fund), http://iris.paho.org/xmlui/bitstream/handle/123456789/34493/9789275119761-eng. pdf? sequence $=1$ \& isAllowed $=y$ (accessed on 7 October 2019).

Penal Reform International (PRI) (2020) Global Prison Trends 2020 (London: PRI), https://cdn.penalreform.org/wp-content/uploads/2020/o5/Global-Prison-Trends-2020-Penal-Reform-International-Second-Edition.pdf (accessed on 13 July 2020$)$.

Ridgeway, C.L. (2009) 'Framed before we know it: How Gender Shapes Social Relations', Gender and Society, 23(2), pp. 145-16o.

Ridgeway, C.L. and S.J. Correll (2004) 'Unpacking the Gender System: A Theoretical Perspective on Gender Beliefs and Social Relations', Gender and Society, 18(4), pp. 510-531.

Romero Mendoza, M., I. Lozano-Verduzco, G. Saldivar and Q. Manriquez Montiel (2018) "Something that could get rid of the cold inside" Women's motives for using addictive substances from a gender perspective', Journal of Substance Abuse, 23(5), November, pp. 466-470.

Sander, G., S. Shirley-Beavan and K. Stone (2019) 'The Global State of Harm Reduction in Prisons', Journal of Correctional Health Care, 24(2), May, pp. 105-120, D OI: 10.1177/ 1078345819837909 (accessed on 27 March 2020). 
UN Chief Executives Board for Coordination (2019) Summary of Deliberations, CEB/ 2018/2 (New York: United Nations), https://www.unsystem.org/CEBPublicFiles/ CEB-2018-2-SoD.pdf (accessed on 24 March 2020).

UN CND (United Nations Commission on Narcotic Drugs) (2019) Implementation of all International Drug Policy Commitments. Follow-up to the 2019 Ministerial Declaration "Strengthening Our Actions at the National, Regional and International Levels to Accelerate the Implementation of Our Joint Commitments to Address and Counter the World Drug Problem (Vienna: UNODC), https://www.unodc.org/documents/hlr/ 19-V1905795_E_ebook.pdf (accessed on 24 March 2020).

UN CND (2016) Mainstreaming a Gender Perspective in Drug-related Policies and Programmes. Resolution 59/5 (Vienna: UNODC), https://www.unodc.org/documents/ commissions/CND/CND_Sessions/CND_59/Resolution_59_5.pdf (accessed on 8 October 2019).

UNDP (United Nations Development Program) (2018) Human Development Indices and Indicators. 2018 Statistical Update (New York: United Nations), http://hdr.undp.org/ en/content/human-development-indices-indicators-2018-statistical-update (accessed on 7 October 2019).

UN General Assembly (2016) Our joint commitment to effectively addressing and coun-

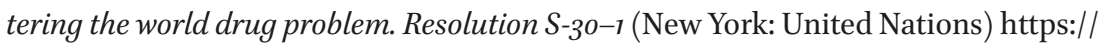
www.unodc.org/documents/postungass2o16/outcome/V16o3301-E.pdf (accessed on 8 October 2019).

UN General Assembly (2015) Transforming our world: the 2030 Agenda for Sustainable Development. A/RES/7o/r (New York: United Nations) https://www.un.org/en/development/desa/population/migration/generalassembly/docs/globalcompact/A_ RES_7O_1_E.pdf (accessed on 1 December 2019).

UnODC (United Nations Office on Drugs and Crime) (2019) World Drug Report 2019 (Vienna: UNODC), https://wdr.unodc.org/wdr2o19/ (accessed on 7 October 2019).

UNODC (2018a) Global Study on Homicide. Gender-related Killing of Women and Girls (Vienna: UNODC), https://www.unodc.org/documents/data-and-analysis/ GSH2018/GSH18_Gender-related_killing_of_women_and_girls.pdf (accessed on 7 October 2019).

UNODC (2018b) World Drug Report 2018. Women and Drugs: drug use drug supply and their consequences (Vienna: UNODC), https://www.unodc.org/wdr2018/prelaunch/ WDR18_Booklet_5_WOMEN.pdf (accessed on 7 October 2019).

UNODC (2008) Word Drug Report 2008 (Vienna: UnODC), https://www.unodc.org/documents/wdr/WDR_20o8/WDR_2008_eng_web.pdf (accessed on 7 October 2019).

UN Women (2014) A Gender Perspective on the Impact of Drug Use, the Drug Trade, and Drug Control Regimes, https://www.unodc.org/documents/ungass2016/Contributions/UN/Gender_and_Drugs_-_UN_Women_Policy_Brief.pdf (accessed on 8 October 2019). 
Uusküla, A., M. Raag, S. Vorobjov and D.D. Jarlais (2018) 'Another frontier for harm reduction: contraceptive needs of females who inject drugs in Estonia, a crosssectional study', Harm Reduction Journal, 15, DoI: 10.1186/s12954-018-0215-o (accessed on 27 March 2020).

Verhellen, E. (2015) 'The Convention on the Rights of the Child. Reflections from a Historical, Social Policy and Educational Perspective' in W. Vandenhole, E. Desmet, D. Reynaert and S. Lembrechts (eds) Routledge International Handbook of Children's Rights Studies (New York and London: Routledge Taylor \& Francis Group), pp. 43-59.

Walby, S. (1989) 'Theorising Patriarchy', Sociology, 23(2), pp. 213-234.

Walby, S., J. Amstrong and S. Strid (2012) 'Intersectionality: Multiple Inequalities in Social Theory', Sociology, 46(2), pp. 224-240.

Wallach Scott, J. (2008) Género e historia (Mexico City: Universidad Autónoma de la Ciudad de México and Fondo de Cultura Económica).

Walmsley, R. (2018) World Prison Population List (twelfth edition) (London: Institute for Criminal Policy Research), https://www.prisonstudies.org/sites/default/files/ resources/downloads/wppl_12.pdf (accessed on 8 October 2019).

Walmsley, R. (2017) World Female Imprisonment List (fourth edition) (London: Institute for Criminal Policy Research), https://www.prisonstudies.org/sites/default/files/ resources/downloads/world_female_prison_4th_edn_v4_web.pdf (accessed on 8 October 2019).

WEF (World Economic Forum) (2018) The Global Gender Gap Report (Geneva: World Economic Forum), http://www3.weforum.org/docs/wef_GGGR_2018.pdf (accessed on 7 October 2019).

wOLA (Washington Office on Latin America), IDPC (International Drug Policy Consortium), ICM (Inter-American Commission of Women) and Dejusticia (2016) Women, Drug Policies and Incarceration: A Guide for Policy Reform in Latin America and the Caribbean (Washington D.C.: Washington Office on Latin America), https://www. wola.org/wp-content/uploads/2016/o2/Women-Drug-Policies-and-IncarcerationGuide_Final.pdf (accessed on 8 October 2019). 